\title{
Inflation Targeting and Macroeconomic Stabilization
}

\author{
Mehdi Monadjemi ${ }^{1} \&$ John Lodewijks ${ }^{1}$ \\ ${ }^{1}$ Australian School of Business, University of New South Wales, Sydney, Australia \\ Correspondence: Mehdi Monadjemi, Australian School of Business, University of New South Wales, Sydney 2052, \\ Australia.E-mail:m.monadjemi@unsw.edu.au
}

Received: July 19, 2014

Accepted: August 3, 2014

Online Published: August 12, 2014

doi:10.5430/rwe.v5n2p93

URL: http://dx.doi.org/10.5430/rwe.v5n2p93

\begin{abstract}
Inflation targeting has been a key objective of the European Monetary Union. This article presents empirical evidence indicating that this macroeconomic objective has been successfully achieved. However, despite expectations that inflation control would provide the foundation for robust and healthy growing economies, other important macroeconomic outcomes have not been achieved. This suggests that inflation targeting is not a sufficient condition for macroeconomic stabilization.
\end{abstract}

Keywords: central banking, inflation targeting, macroeconomic stabilization, financial crises

\section{Introduction}

In 1991, the Maastricht Treaty set various stages for the creation of the European Monetary Union (EMU) and the introduction of the Euro. The Treaty specified the economic entry conditions for the member states in terms of the inflation rate, the interest rate and the government budget deficit and debt. The existence of these conditions allows all of the member countries to enter the union with relative financial stability. Formation of a monetary union commits a country to price stability. The EMU members operate with a common central bank and a common currency so that each individual country loses control over its independent monetary and exchange rate policy. The purpose of this paper is to examine success of EMU countries in controlling inflation. The article presents empirical evidence indicating that this macroeconomic objective has been successfully achieved. The review of literature is presented in Section 1.The role of the central bank is discussed in Section 2. Empirical evidence and some macroeconomic consequences are offered in Sections 3 and 4.

\section{Review of Literature}

Alesina and Barro (2002) argue that forming a monetary union with a committed anchor benefits the commitment to price stability against the cost of losing an independent monetary policy. The authors show that the benefits are maximized for small monetarily irresponsible countries trading heavily with a large partner whose business cycles are symmetric with that of the small potential member. Mundell (1961) introduced the importance of symmetrical business cycles in his theory of optimum currency areas. The creation of a monetary union can be beneficial when exports and imports between member countries are high, factors of production are mobile and the business cycles are symmetric. If these conditions are not met, the costs of moving from a floating exchange rate to a single currency exceed the benefits. Other studies in this area such as McKinnon (1963) introduced the proportion of tradable and non-tradable goods and Kenen (1969) discussed the extent of industrial specialization. In Mundell's model (1961) labour mobility is an important condition. If labour is mobile there is no need to implement different monetary policies in various regions. The labour moves from the depressed areas to more prosperous regions and unemployment will not remain high in depressed regions. Ingram (1973) argued that capital mobility might substitute for labour mobility if labour is relatively rigid and immobile.

Eichengreen (1991) argues that symmetry of the business cycles leads to the stability of the real exchange rate. Poloz (1990) examined the behaviour of the real exchange rate in Canadian provinces with Britain, France, Germany and Italy and showed that the real exchange rate is more stable among the four European countries than in Canada. Eichengreen (1991) used a similar approach with wider sample including 10 European countries and 4 regions in the United States and Canada. The results of this study showed that the real exchange rate is more stable in the United States and Canada than in Europe. Eichengreen examined correlation of share prices in Paris and Dusseldorf with share prices in Montreal and Toronto as a proxy for symmetry of the business cycles. The results of the study showed 
that share prices are more correlated in Canada than in Europe. To justify using correlation of share prices, Eichengreen argued that share prices reflect present value of the future and current profitability of enterprises. Enterprises' profits in different regions are different when shocks are asymmetric. Accordingly, correlation of share prices tends to be a good proxy for the symmetry of the business cycles.

The EMU consciously withdrew the policy sovereignty of member countries in order to (i) reduce the exchange rate volatility of smaller countries by adopting the euro and (ii) promote price stability through the inflation targeting strategy of the European Central Bank.

\section{The Role of the Central Bank}

The European System of Central Bank (ESCB) includes a central bank in Frankfort and 17 national central banks located in each member country. The Masstricht Treaty of 1991emphasised the importance of an independent central bank that is not influenced by the inflationary policies of the national governments. Accordingly, the goal of price stability became the prime objective of the ESCB.

Under a fixed exchange rate system such as Bretton Woods and the European Monetary System (EMS) that operated before the EMU, the monetary policies of the member countries informally is directed by the monetary policy of the central bank of the largest economy. Under the Bretton Woods system the U.S. Federal Reserve System, and in the EMS the central bank of Germany, assumed the task of monetary policy coordination. For example, under the Bretton Woods arrangement all of the exchange rates relative to the US dollar were fixed. If the Federal Reserve Bank exercised expansionary monetary policy and lowered US interest rates, all of the other countries should follow the action of the Fed, otherwise their respective currencies appreciate.

Without such arrangement, maintenance of the fixed exchange rate system becomes impossible as some countries are tempted to devalue by conducting expansionary monetary policy. In a monetary union, the task of monetary policy must formally be controlled by a single central bank. Otherwise, high inflation countries by printing large quantity of common currency could create monetary instability for the whole union.

To illustrate the above argument, Krugman (1995) assumed that the monetary union consists of two countries with $\mathrm{n}_{1}$ and $n_{2}$ population, where $n_{1}>n_{2}$. Each country attempts to maximize its individual seignorage, given the level of the seignorage of the other country. In this hypothetical example the rate of inflation in each country is:

$$
\begin{array}{r}
\Pi_{1}=\frac{\mathrm{n} 1+\mathrm{n} 2}{\beta \mathrm{n}_{1}} \\
\Pi_{2}=\frac{\mathrm{n} 1+\mathrm{n} 2}{\beta \mathrm{n}_{2}}
\end{array}
$$

where $\Pi_{1}, \Pi_{2}$ and $\beta$ (Note 1) are the inflation rates in countries 1 and 2 respectively and $\beta$ is the coefficient of the rate of inflation in the utility function of each country's central bank. The inflation rate of the smaller country is higher and this country by printing and circulating more common currency receives more seignorge and ultimately generates monetary instability throughout the union. To prevent this problem there must be a single central bank for the whole union which is responsible for printing common currency.

\section{Empirical Results}

In this section we test to see if the EMS, and later the EMU, did indeed promote price stability in the region. All of the data were collected from the OECD website under national income accounts.

In 1979, in the context of EMS, eight European countries decided to limit fluctuations of their exchange rates within \pm 2.5 percent relative to the German Mark. The EMS was successful in keeping the inflation rates of the member countries in line with the rate of inflation in Germany, the lowest rate in Europe. The EMS actively continued operation until 1992 when a significant depreciation of the British Pound, and increasing limit of fluctuations to \pm 15 percent automatically, caused breakdown of the system. Eventually the European Monetary Union and the single currency were established in 1999. Adapted from Krugman and Obstfeld (2006), the impressive success of EMS in controlling inflation, known as the credibility theory of EMS, is apparent from Figure 1. For example, the inflation differential of 10 percent between Ireland and Germany in 1979 was reduced to 0 percent in 1992. By fixing their exchange rate against DM, members of EMS imported the German central bank's credibility as an effective controller of inflation, causing lower inflationary expectations and discouraging monetary expansion at home.

The commitment of the ECB in controlling inflation is shown in Figure 2. The average inflation of about 12 percent in 1992 was reduced to 1.5 percent in 2013 and still is falling. 
In Figure 3 inflation rates of four major Euro Zone countries 1970 - 2010 are plotted. It is evident that inflation rates were high and volatile prior to the introduction of single currency in late 1990s. Further evidence on the stability and control of inflation in the Euro zone major countries is shown in Table 1 and 2. Standard deviations and sums of inflation rates are significantly higher in the period $1970-1999$ than in $2000-2013$.

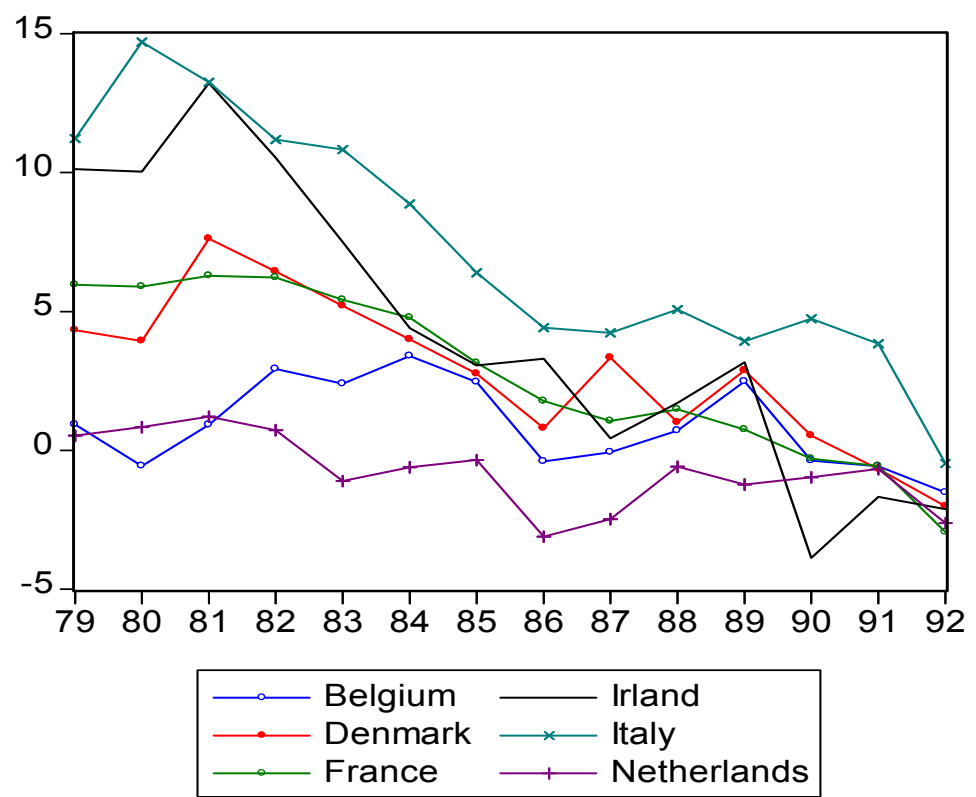

Figure 1. Inflation differential with Germany

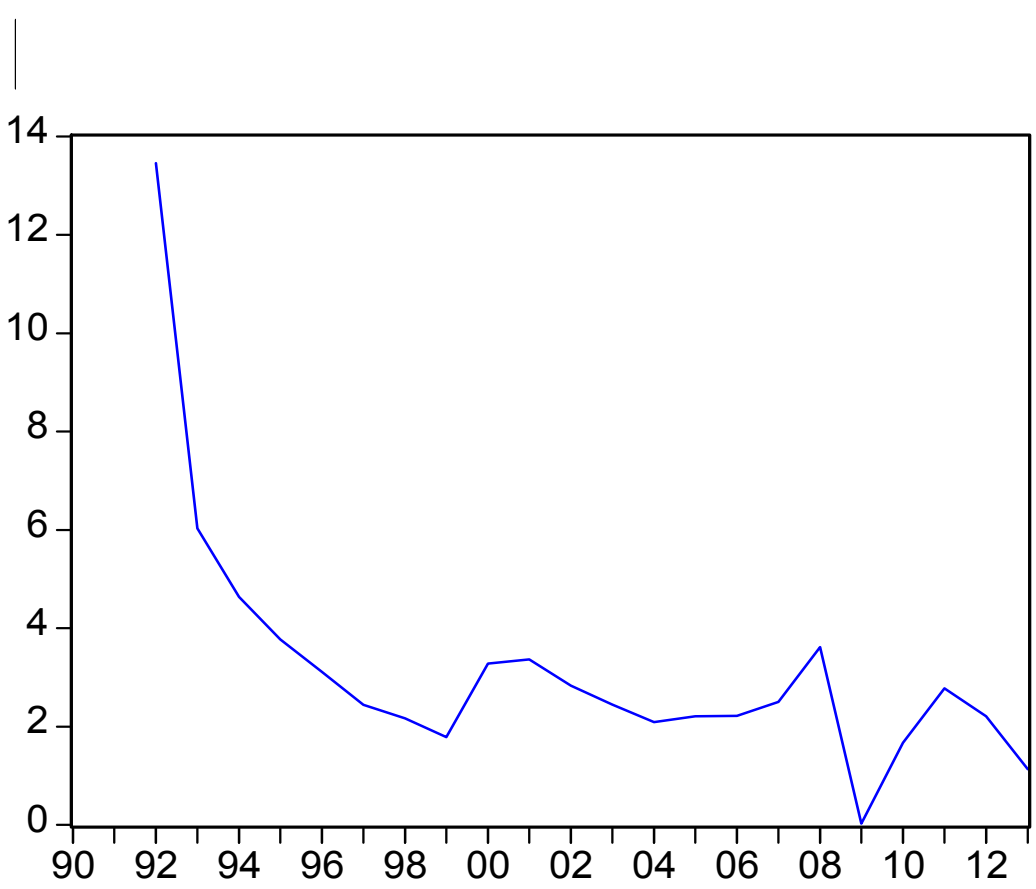

Figure 2. Average inflation 12 members of EMU 1990-2013

The 12 countries in Figure 2 are members of EMU that are also members of OECD. Data on these countries are continuously available from $1990-2013$. 


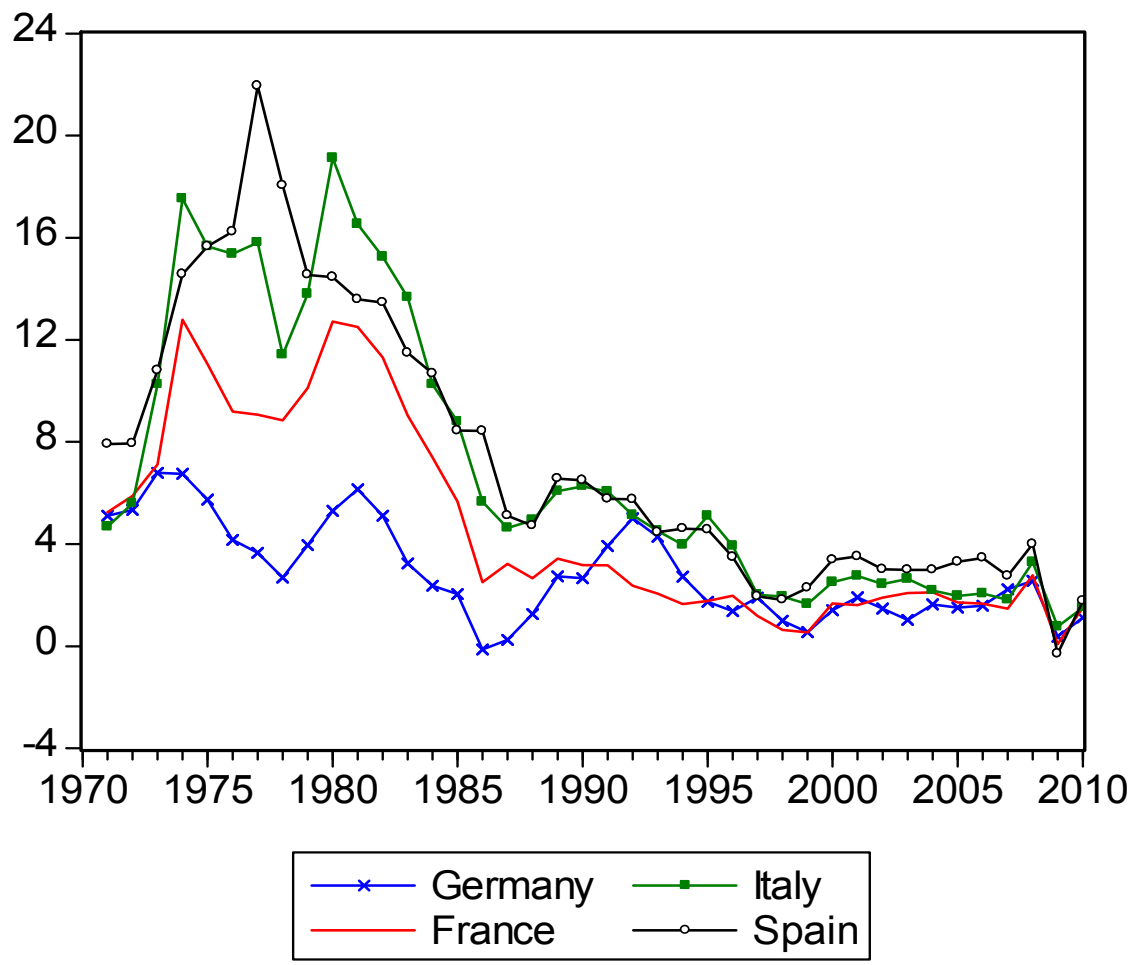

Figure 3. Inflation in four major Euro zone countries

Table 1. Properties of inflation rates four major euro zone countries 1970 - 1999

\begin{tabular}{lllll}
\hline Countries & France & Germany & Italy & Spain \\
\hline Standard Dev. & 4.06 & 1.97 & 5.38 & 5.33 \\
\hline Sums & 168.36 & 97.7 & 255.6 & 265.9 \\
\hline
\end{tabular}

Table 2. Properties of inflation rates four major euro zone countries 2000 - 2010

\begin{tabular}{lllll}
\hline Countries & France & Germany & Italy & Spain \\
\hline Standard Dev. & 0.59 & 0.59 & 0.67 & 1.17 \\
\hline Sums & 18.6 & 16.9 & 23.9 & 30.9 \\
\hline
\end{tabular}

Further evidence on inflation targeting is provided using Hodrick-Prescott (1997) (HP) filter.

HP method divides a time series into growth and cyclical components. Using a statistical filter, the growth component can be removed, leaving the cyclical component as deviations around a smooth trend line. Assume Y is a time series on real GDP or CPI.

$\mathrm{Y}=y_{c}+y_{g}$ Where $y_{c}$ and $y_{g}$ respectively are cyclical and growth components of $\mathrm{Y}$.

In Figure 4 the trend of average inflation in 4 major EMU counties was rising until early 1980s, started to decline thereafter and stabilized after introduction of a single currency in 2000 . This trend may be as result of a combination EMS and inflation control policies of the European central bank. Germany, France and Italy were members of EMS when it was operative until 1992. 

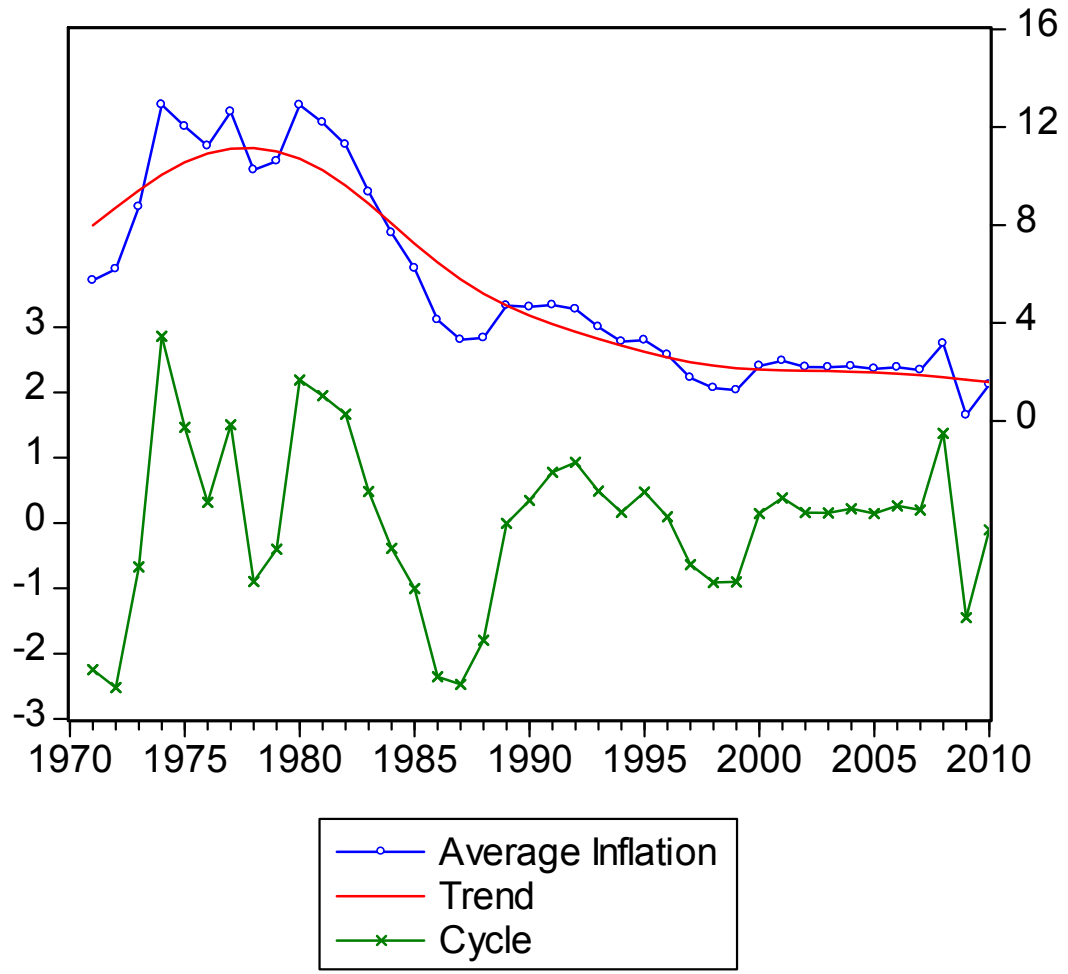

Figure 4. Hodrick-Prescott filter average inflation 4 major EMU countries

Since the introduction of euro in 1999, The European Monetary Union (EMU) has effectively been able to maintain a low rate of inflation. Monadjemi, Yoon and Lodewijks (2012) also argued that prior to the introduction of euro, the European Monetary System (EMS) reduced the rate of inflation in eight member countries to a very low level, equivalent to the rate of inflation in Germany. However, the debt problem of the EMU peripheries over shadowed the success of the monetary union in controlling the inflation.

\section{Macroeconomic Consequences (Note 2)}

The empirical evidence presented in this article indicates that inflation targeting has been highly successful in maintaining price stability in the region. However, despite expectations that inflation control would provide the foundation for robust and healthy growing economies, other important macroeconomic outcomes have not been achieved. Eurozone economies were the most adversely affected by the Global Financial Crisis and there appears little likelihood of improvement in macroeconomic outcomes in the foreseeable future.

The Global Financial Crisis (GFC) had a devastating impact on many EMU member countries and resulted in growing public and private sector indebtedness, the collapse of economic activity, high levels of unemployment, particularly for youth, and the threat of deflation. The ECB's decision to reduce its main refinancing rate in June 2014 from $0.25 \%$ to $0.15 \%$ was accompanied by the deposit rate on excess reserves also being reduced by $0.10 \%$ (from $0 \%$ to $-0.10 \%$ ). The tax on excess reserves represents an attempt to avoid deflation in the Eurozone by promoting bank lending.

Furthermore, as austerity measures were implemented in the UK, Ireland, Spain, Italy, Greece, Portugal and France, the results have been associated with high unemployment and rising social tensions. The strategy of internal devaluation has been employed as the traditional approach of restoring competiveness through currency devaluation is no longer available. Currency devaluations cut the purchasing power of consumers by making the national currency weaker and thus foreign goods more expensive. This has the virtue of increasing consumption of domestically produced goods, while making exports cheaper. This option is no longer available as national currencies have disappeared. So they are left with internal devaluations by cutting wages across the board. While 
internal devaluations have contributed to reduced current account deficits this has resulted from repressed domestic demand, due to wage cuts and increased unemployment, which has led to a collapse in import spending. Further, an internal devaluation exacerbates the burdens of servicing private debt and further dampens any hope of a recovery in private demand as the income of consumers has been reduced.

Not surprisingly, the design of the EMU has been subject to intense scrutiny. The chief challenge to such a monetary union was the different levels of productivity between the higher productivity of the older member states of the West and the newer, lower productivity members from the East. The presence of asymmetric shocks was also a key problem. Furthermore, within the Eurozone, the centralisation of monetary policy condoned housing bubbles in Spain and Ireland prior to the GFC. The strategy of internal devaluation, combined with budgetary austerity, has had a strong negative impact in terms of growth and employment throughout Europe and led to the near collapse of Europe's 'Social Model' (balancing unrestrained market forces by a 'social dimension') with social safety nets disappearing or severely reduced.

Increased doubts are being expressed about the conventional view of a low inflation strategy, Blanchard et al. (2010) made an important observation that higher average inflation and higher nominal interest rates to start with, would have helped to lower interest rates more, thereby most likely reducing the decline in output and deterioration of fiscal positions in the aftermath of global crisis. This reservation against the low inflation strategy has been shared by leading economists such as Kenneth Rogoff, Greg Mankiw, Paul Krugman, and Brad DeLong.

Some observers are even suggesting that countries need to restore their policy sovereignty. This inevitably involves exiting the EMU and reinstating a fiat (non-convertible) currency, a flexible exchange rate regime and monetary independence. Whether such a radical strategy ensues, it does suggest quite clearly that a monetary union with a singular focus on inflation targeting can achieve inflation control but this is clearly not a sufficient condition for macroeconomic stabilization.

\section{References}

Alesina, A., \& Barro, R. (2002). Currency Union. Quarterly Journal of Economics, CXVII, 409-436. http://dx.doi.org/10.1162/003355302753650283

Blanchard, O, Dell'Ariccia, G., \& Mauro, P. (2010). Rethinking Macroeconomic Policy. Journal of Money, Credit and Banking, 42(supplement, 6), 199-215. http://dx.doi.org/10.1111/j.1538-4616.2010.00334.x

Eichengreen, B. (1991). Is Europe an Optimum Currency Area? NBER Working Paper Series, No. 3579.

Hordick, R. J., \& Prescott, E. C. (1997). Post-War US Business Cycles: An Empirical Investigation. Journal of Money, Credit and Banking, 29, 1-16. http://dx.doi.org/10.2307/2953682

Ingram, J. (1973, April). The Case for European Monetary Integration. Princeton Essay in International Finance, 98 , $1-33$.

Kenen, P. (1969). The Theory of Optimum Currency Area: An Eclectic View. In Robert A., \& Krugman, P. (Eds.), Currency and Crises (1995). MIT Press, Cambridge MA.

Krugman, P. (1995). Currency and Crises. Cambridge MA: MIT Press, pp. 196-198.

Krugman, P., \& Obstfeld, M. (2006). International Economics: Theory and Policy ( $7^{\text {th }}$ ed.).Pearson Addison Wesely.

McKinnon, R. (1963). Optimum Currency Area. American Economic Review, 53, 717-725.

Monadjemi, M., Yoon, K., \& Lodewijks, J. (2012, September). Success and Failure of a Monetary Union. Online Journal of Social Sciences Research, 1(7), 213-220.

Mundell, RA. (1961). A theory of optimum currency areas. American Economic Review, 51(4), 657-665.

Poloz, S. (1990). Real Exchange Rate Adjustment Between Regions in a Common Currency Area. Unpublished, Bank of Canada.

\section{Notes}

Note 1 . The utility function of each central bank is $\mathrm{W}=\mathrm{r}-\beta \Pi \mathrm{i}$, where $\mathrm{r}$ is the real seinorage and $\mathrm{W}$ is the utility of the central bank.

Note 2. In preparing this article we have greatly benefited in reading papers prepared for a special issue of the Economic and Labour Relations Review to be published in 2014 on Austerity and the EuroCrisis. 